\title{
KINERJA KEUANGAN DAERAH KABUPATEN / KOTA SEBELUM DAN SETELAH PEMEKARAN DAERAH SUMATERA SELATAN
}

\section{THE FINACIAL PERFORMANCE OF THE DISTRICT OR THE CITY BEFORE AND AFTER THE EXPANSION AREA IN SOUTH SUMATERA}

\author{
Benta Palantama Putra ${ }^{1}$, Retno Ulfayatun Hidayah ${ }^{2}$ \\ Sekolah Tinggi Ilmu Ekonomi dan Bisnis Prana Putra ${ }^{1,2}$ \\ benta@stiebipranaputra.ac.id ${ }^{1}$
}

\begin{abstract}
In line with the spirit of regional autonomy, regional performance is measured through the ability of the region to manage and manage its own households. This study aims to analyze the financial performance of district / city areas before and after the division of regions in southern Sumatra. This type of research used in this research is quantitative descriptive. The sampling technique used was purposive sampling with a number of 6 parent districts experiencing expansion in the South Sumatra region. Data were analyzed in this test using $t$ test (paired $t$-test). The results of this study indicate that: 1) measured from the fiscal decentralization ratio there are differences in the financial performance of the district government before and after the division in South Sumatra Province because the Total Local Revenue (PAD) has increased after the division; 2) measured from the ratio of capital expenditure harmony there are differences in the financial performance of district governments before and after the division in South Sumatra Province because capital expenditure (development) has increased after the division; 3) measured from the growth ratio of PAD there is no difference in the financial performance of district governments before and after the division in South Sumatra Province because the Regional Original Revenue (PAD) has not changed; 4) measured from the ratio of regional financial dependency there is no difference in the financial performance of the district government before and after the division in South Sumatra Province because the transfer revenue with total regional income has not changed.
\end{abstract}

Keywords : Financial Performance, Regional Expansion,

\begin{abstract}
ABSTRAK
Sejalan dengan semangat otonomi daerah, kinerja daerah terukur melalui kemampuan daerah mengatur dan mengurus rumah tangga sendiri. Penelitian ini bertujuan untuk menganalisis kinerja keuangan daerah kabupaten/kota sebelum dan setelah pemekaran daerah di sumatera selatan. Jenis penelitian yang digunakan dalam penelitian ini deskriptif kuantitatif. Teknik pengambilan sampel yang digunakan adalah purposive sampling dengan jumlah 6 kabupaten induk yang mengalami pemekaran di wilayah Sumatera Selatan. Data dianalisis dalam pengujian ini menggunakan uji t (paired t-test). Hasil dari penelitian ini menunjukkan bahwa: 1) diukur dari rasio desentralisasi fiskal terdapat perbedaan kinerja keuangan pemerintah daerah kabupaten sebelum dan setelah pemekaran di Provinsi Sumatera Selatan dikarenakan Total Pendapatan Asli Daerah
\end{abstract}


(PAD) mengalami peningkatan setelah pemekaran; 2) diukur dari rasio keserasian belanja modal terdapat perbedaan kinerja keuangan pemerintah daerah kabupaten sebelum dan setelah pemekaran di Provinsi Sumatera Selatan dikarenakan belanja modal (pembangunan) mengalami peningkatan setelah pemekaran; 3) diukur dari rasio pertumbuhan PAD tidak terdapat perbedaan kinerja keuangan pemerintah daerah kabupaten sebelum dan setelah pemekaran di Provinsi Sumatera Selatan dikarenakan Pendapatan Asli Daerah (PAD) tidak mengalami perubahan; 4) diukur dari rasio ketergantungan keuangan daerah tidak terdapat perbedaan kinerja keuangan pemerintah daerah kabupaten sebelum dan setelah pemekaran di Provinsi Sumatera Selatan dikarenakan pendapatan transfer dengan total pendapatan daerah tidak mengalami perubahan.

Kata Kunci : Kinerja Keuangan, Pemekaran Daerah, Pendapatan Daerah

\section{PENDAHULUAN}

Otonomi daerah adalah kewenangan daerah untuk mengatur dan mengurus kepentingan masyarakat setempat menurut prakarsa sendiri berdasarkan aspirasi masyarakat dalam ikatan Negara Kesatuan Republik Indonesia. Otonomi daerah yang sekarang disebut pemekaran daerah merupakan suatu kebijakan yang memiliki tujuan mulia untuk mendukung pemerataan pembangunan yang dibutuhkan daerah. Pembangunan yang dimaksud adalah pembangunan yang meliputi berbagai aspek termasuk salah satunya adalah yang berhubungan dengan aspek finansial/keuangan. Hal ini sesuai dengan tujuan otonomi daerah yaitu agar tidak terjadi pemusatan di dalam kekuasaan pemerintahan pada tingkat pusat sehingga jalan pemerintah serta pembangunan berjalan lancar.

Sejalan dengan semangat otonomi daerah, kinerja daerah terukur melalui kemampuan daerah mengatur dan mengurus rumah tangga sendiri. Kaho (Kaho, 1997) menyatakan bahwa salah satu kriteria yang penting untuk mengetahui secara nyata kemampuan daerah dalam mengatur dan mengurus rumah tangganya adalah self supporting dalam bidang keuangan. Hal ini berarti bahwa keuangan merupakan faktor esensial dalam mengukur tingkat kemampuan daerah dalam melaksanakan otonominya.

Pemekaran daerah atau wilayah di Provinsi Sumatera Selatan telah terjadi beberapa kali khususnya pembentukan Daerah Otonomi Baru (DOB) kabupaten/kota. Hal ini seperti yang dikatakan oleh Hendri Zainudin anggota Dewan Perwakilan Daerah (DPD) Sumatera Selatan bahwa terdapat 17 Kabupaten/Kota yang ada di Provinsi Sumatera Selatan. Menurutnya pembentukan daerah otonomi baru (DOB) menjadi solusi terbaik untuk memajukan daerah. Seperti yang digambarkan dalam ringkasan berikut:

1) Kota Lubuklinggau merupakan pemekaran dari Kabupaten Musi Rawas pada tanggal 21 Juni 2001, 2) Kota Pagar Alam merupakan pemekaran dari Kabupaten Lahat pada tanggal 21 Juni 2001, 3) Kota Prabumulih merupakan pemekaran dari Kabupaten Muara Enim pada tanggal 21 Juni 2001, 4) Kabupaten Banyuasin merupakan pemekaran dari Kabupaten Musi Banyuasin pada tanggal 2 Juni 2002, 5) Kabupaten Ogan Ilir merupakan pemekaran dari Kabupaten Ogan Komering Ilir pada tanggal 18 Desember 2003, 6) Kabupaten Ogan Komering Ulu Timur merupakan pemekaran dari Kabupaten Ogan Komering Ulu pada Tanggal 18 
Desember 2003, 7) Kabupaten Ogan Komering Ulu Selatan merupakan pemekaran dari Kabupaten Ogan Komering Ulu pada tanggal 16 Januari 2004, 8) Kabupaten Empat Lawang merupakan pemekaran dari Kabupaten Lahat pada tanggal 20 April 2007, 9) Kabupaten Panukal Alab Lematang Ilir (PALI) merupakan pemekaran dari Kabupaten Muara Enim pada tanggal 11 Januari 2013, 10) Kabupaten Musi Rawas Utara merupakan pemekaran dari Kabupaten Musi Rawas pada tanggal 11 Juni 2013.

Berdasarkan fenomena di atas pemekaran daerah di Provinsi Sumatera Selatan kiranya dapat meningkatkan kualitas hidup masyarakat yang mulanya ditunjukan oleh meningkatnya kinerja keuangan dari pemerintah daerah pemekaran tersebut. Berbagai penelitian menemukan hasil yang beragam mengenai hasil perbandingan tentang kinerja keuangan sebelum dan setelah pemekaran yang dialami oleh pemerintah daerah yang mengalami pemekaran. Menurut Sucandrawati (2016) kinerja keuangan ini menjadi tolak ukur keberhasilan atas kebijakan pemekaran wilayah yang diambil oleh pemerintah daerah. Untuk melihat perkembangan suatu daerah pemekaran atau daerah otonomi baru, diperlukan adanya perbandingan kinerja daerah tersebut sebelum dan setelah pemekaran. Dari hal itu akan terlihat apakah terjadi perubahan kemajuan yang signifikan pada suatu daerah setelah dimekarkan. Menurut Bappenas (2008) Pendekatan seperti ini dapat dianggap kurang tepat bila tidak ada pembanding yang setara. Namun perbandingan dapat dilakukan antara daerah induk dan daerah otonomi baru sehingga dapat dilihat bagaimana dampak yang terjadi di kedua daerah tersebut setelah pemekaran. Perbandingan ini juga dilakukan terhadap perkembangan rata-rata daerah kabupaten/kota dalam satu provinsi yang sama. Hal ini dimaksud untuk melihat secara umum kondisi daerah otonomi baru, daerah induk, dan daerah sekitarnya.

Penelitian Wulansari (2018) dapat disimpulkan bahwa kinerja keuangan pemerintah Kabupaten Asahan sebelum dan sesudah otonomi daerah belum dapat dikatakan baik dikarenakan ketergantungan terhadap bantuan pemerintah pusat masih tinggi, belum tercapainya target penerimaan PAD, sebelum otonomi daerah, terpusatnya dana APBD pada belanja rutin dbandingkan belanja pembangunan. Hasil penelitian Imelda (2015) menunjukan bahwa terdapat perbedaan yang signifikan rasio desentralisasi fiskal, kamandirian, kemampuan pembiayaan, efisiensi dan efektifitas, ketergantungan dan kontribusi BUMD dalam pencapaian kinerja keuangan sebelum dan sesuah otonomi daerah.

Berdasarkan pertimbanganpertimbangan tersebut maka peneliti tertarik untuk melakukan penelitian dengan teori yang sama tetapi waktu yang berbeda dengan peneliti sebelumnya. Dengan menganalisa kinerja keuangan sebelum dan setelah pemekaran Kabupaten/Kota Provinsi Sumatera Selatan, apakah kinerja pemerintah sebelum pemekaran dan setelah pemekaran sudah mempercepat pendapatan asli daerah dan mengurangi terhadap pemerintah pusat sebaliknya.

Tujuan penelitian ini untuk mengetahui kinerja keuangan pemerintah daerah Kabupaten/Kota sebelum dan setelah pemekaran daerah berdasarkan: rasio desentralisasi fiskal, rasio keserasian belanja modal, rasio pertumbuhan PAD, dan rasio ketergantungan keuangan daerah. 


\section{METODE PENELITIAN}

Jenis penelitian yang digunakan dalam penelitian ini deskriptif kuantitatif. Teknik pengambilan sampel yang digunakan adalah purposive sampling dengan jumlah 6 kabupaten induk yang mengalami pemekaran di wilayah Sumatera Selatan. Data dianalisis dalam pengujian ini menggunakan uji $\mathrm{t}$ (paired t-test) dengan menggunakan software SPSS 16.0 .

\section{Analisis Rasio Keuangan Uji Normalitas}

Normalitas data dapat dilihat melalui besarnya asymptotic significance, Adapun pedoman pengambilan keputusan kenormalan distribusi adalah sebagai berikut, jika signifikansi atau nilai probabilitas $(\alpha)<0,05$, maka distribusi tidak normal tapi $(\alpha)>0,05$, maka distribusi normal.

\section{Uji Beda (T-Paired)}

Dari hasil pengujian, apabila signifikansi $>0,05$ maka hipotesis ditolak, sedangkan apabila signifikansi $<0,05$ maka hipotesis diterima.

\section{HASIL DAN PEMBAHASAN}

Tabel 1. Hasil Statistik Deskriptif (\%)

\begin{tabular}{|c|c|c|c|c|}
\hline & Minimum & Maksimum & Mean & Std.deviation \\
\hline DFSB & 1.21 & 7.19 & 4.3096 & 1.38810 \\
\hline DFST & 1.55 & 10.50 & 5.1132 & 2.16170 \\
\hline KBMSB & 7.32 & 42.47 & 19.8443 & 11.30972 \\
\hline KBMST & 12.52 & 51.65 & 27.8864 & 10.56590 \\
\hline PPADSB & -30.13 & 518.93 & 65.2168 & 116.94603 \\
\hline PPADST & -60.25 & 59.42 & 11.6125 & 25.96499 \\
\hline KKDSB & 74.38 & 97.54 & 90.4039 & 5.30195 \\
\hline KKDST & 69.07 & 95.50 & 87.5579 & 7.17814 \\
\hline
\end{tabular}

Sumber: Data diolah (2018)

Keterangan :

DFSB = Desentralisasi Fiskal Sebelum

DFST = Desentralisasi Fiskal Setelah

KBMSB = Keserasian Belanja Modal Sebelum

KBMST = Keserasian Belanja Modal Setelah

PPADSB = Pertumbuhan PAD Sebelum

PPADST = Pertumbuhan PAD Setelah

KKDSB = Ketergantungan Keuangan Daerah Sebelum

KKDST = Ketergantungan Keuangan Daerah Setelah 
Tabel 2. Hasil Uji T (T-Paired)

\begin{tabular}{lcccc}
\hline & Mean & $\mathbf{t}$ & Sig & Kesimpulan \\
\hline DFSB- DFST & -.80357 & -2.970 & .006 & H1 diterima \\
\hline $\begin{array}{l}\text { KBMSB- } \\
\text { KBMST }\end{array}$ & $-2.50487 \mathrm{E} 1$ & -12.609 & .000 & H2 diterima \\
\hline $\begin{array}{l}\text { PPADSB- } \\
\text { PPADST }\end{array}$ & -8.5164 & -1.539 & .138 & H3 ditolak \\
\hline $\begin{array}{l}\text { KKDSB- } \\
\text { KKDST }\end{array}$ & 2.84607 & 1.968 & .059 & H4 ditolak \\
\hline
\end{tabular}

Sumber: Data diolah, 2018

Dilihat dari probabilitas signifikasi untuk desentralisasi fiskal sebelum dan desentralisasi fiskal setelah sebesar 0.006 lebih kecil dari 0.05 . Berdasarkan hasil ini dapat disimpulkan bahwa terdapat perbedaan kinerja keuangan pemerintah daerah kabupaten sebelum dan setelah pemekaran di Provinsi Sumatera Selatan diukur dari rasio desentralisasi fiskal.

Dilihat dari probabilitas signifikasi untuk keserasian belanja modal sebelum dan keserasian belanja modal setelah sebesar 0.000 lebih kecil dari 0.05. Berdasarkan hasil ini dapat disimpulkan bahwa terdapat perbedaan kinerja keuangan pemerintah daerah kabupaten sebelum dan setelah pemekaran di Provinsi Sumatera Selatan diukur dari rasio keserasian belanja modal.

Dilihat dari probabilitas signifikasi untuk pertumbuhan PAD sebelum dan pertumbuhan PAD setelah sebesar 0.138 lebih besar dari 0.05 . Berdasarkan hasil ini dapat disimpulkan bahwa tidak terdapat perbedaan kinerja keuangan pemerintah daerah kabupaten sebelum dan setelah pemekaran di Provinsi Sumatera Selatan diukur dari rasio pertumbuhan PAD.

Dilihat dari probabilitas signifikasi untuk ketergantungan keuangan daerah sebelum dan ketergantungan keuangan daerah setelah sebesar 0.059 lebih besar dari 0.05 . Berdasarkan hasil ini dapat disimpulkan bahwa tidak terdapat perbedaan kinerja keuangan pemerintah daerah kabupaten sebelum dan setelah pemekaran di Provinsi Sumatera Selatan diukur dari rasio Ketergantungan Keuangan Daerah.

\section{Perbedaan Kinerja Keuangan Daerah Pemekaran dilihat Dari Aspek Desentralisasi Fiskal}

Berdasarkan hasil uji t (t-paired) pengujian hipotesis pertama menyatakan bahwa hipotesis diterima. Dapat disimpulkan bahwa secara statistik terdapat perbedaan kinerja keuangan pemerintah daerah kabupaten sebelum dan setelah pemekaran di Provinsi Sumatera Selatan diukur dari rasio desentralisasi fiskal. Dengan demikian pemekaran daerah telah memberikan dampak perubahan yang signifikan terhadap kinerja keuangan pemerintah daerah induk dilihat dari aspek desentralisasi fiskal.

Hasil penelitian ini sejalan dengan penelitian Meilinda (2010) yang menunjukan bahwa desentralisasi fiskal setelah berlakunya pemekaran daerah lebih baik dari pada sebelum pemekaran daerah. Rendahnya desentralisasi fiskal kabupaten/kota di Provinsi Sumatera Selatan sebelum pemekaran daerah disebabkan bukan hanya karena kabupaten belum mampu 
mengintensifkan penerimaan pajak dan retribusi daerah, tetapi juga ada beberapa sumber PAD yang beralih ke daerah pemekaran ( daerah otonom baru). Hal ini mengakibatkan rendahnya PAD yang menyebabkan proporsi PAD terhadap pendapatan daerah juga rendah. Pemerintah daerah diharapkan mampu menggali dan mengoptimalkan potensi keuangan lokal, khususnya Pendapatan Asli Daerah.

\section{Perbedaan Kinerja Keuangan Daerah Pemekaran dari Aspek Keserasian Belanja Modal}

Berdasarkan hasil uji t (t-paired) pengujian hipotesis kedua menyatakan bahwa hipotesis diterima. Dapat disimpulkan secara statistik terdapat perbedaan kinerja keuangan pemerintah daerah kabupaten sebelum dan setelah pemekaran diukur dari rasio keserasian belanja modal. Dengan demikian pemekaran daerah memberikan dampak perubahan yang signifikan terhadap kinerja keuangan pemerintah daerah induk dilihat dari aspek keserasian belanja modal. Adanya perbedaan kinerja keuangan pada daerah induk setelah pemekaran disebabkan karena realisasi anggaran untuk belanja modal mengalami perubahan yang signifikan meskipun daerah tersebut dimekarkan.

Menurut Susanti (Susanti, 2009) semakin tinggi persentase dana yang dialokasikan pada belanja pelayanan publik (belanja modal) maka dana yang digunakan untuk menyediakan sarana dan prasarana ekonomi masyarakat cenderung semakin besar. Hasil penelitian ini sejalan dengan penelitian yang Anggraeni (Anggraeni , 2015) menguji pengaruh belanja modal terhadap kinerja keuangan yang menunjukkan bahwa belanja modal berpengaruh signifikan terhadap kinerja keuangan.

\section{Perbedaan Kinerja Keuangan Daerah Pemekaran dilihat dari Aspek Pertumbuhan PAD}

Berdasarkan hasil uji t (t-paired) pengujian hipotesis ketiga menyatakan bahwa hipotesis ditolak. Dapat disimpulkan secara statistik tidak terdapat perbedaan kinerja keuangan pemerintah daerah kabupaten sebelum dan setelah pemekaran di Provinsi Sumatera Selatan diukur dari rasio pertumbuhan PAD. Dengan demikian pemekaran daerah tidak memberikan dampak perubahan yang signifikan terhadap kinerja keuangan pemerintah daerah induk dilihat dari aspek pertumbuhan PAD.

Hasil penelitian ini sejalan dengan penelitian Mengkuningtyas (2015) yang menyatakan bahwa tidak terdapat perbedaan kinerja keuangan pemerintah daerah kabupaten/kota sebelum dan setelah pemekaran di Indonesia.

\section{Perbedaan Kinerja Keuangan Daerah Pemekaran dilihat dari Aspek Ketergantungan Keuangan Daerah}

Berdasarkan hasil uji t (t-paired) pengujian hipotesis keempat menyatakan bahwa hipotesis ditolak. Dapat disimpulkan secara statistik tidak terdapat perbedaan kinerja keuangan pemerintah daerah kabupaten sebelum dan setelah pemekaran di provinsi Sumatera Selatan yang diukur dari rasio ketergantungan keuangan daerah. Dengan demikian pemekaran daerah tidak memberikan dampak perubahan yang signifikan terhadap kinerja keuangan pemerintah daerah induk dilihat dari aspek ketergantungan keuangan daerah, hasil penelitian ini sejalan dengan penelitian Mianti (2014). 
PENUTUP

Kesimpulan

Kesimpulan dalam penelitian ini adalah: 1) diukur dari rasio desentralisasi fiskal terdapat perbedaan kinerja keuangan pemerintah daerah kabupaten sebelum dan setelah pemekaran di Provinsi Sumatera Selatan dikarenakan Total Pendapatan Asli Daerah (PAD) mengalami peningkatan setelah pemekaran; 2) diukur dari rasio keserasian belanja modal terdapat perbedaan kinerja keuangan pemerintah daerah kabupaten sebelum dan setelah pemekaran di Provinsi Sumatera Selatan dikarenakan belanja modal (pembangunan) mengalami peningkatan setelah pemekaran; 3) diukur dari rasio pertumbuhan PAD tidak terdapat perbedaan kinerja keuangan pemerintah daerah kabupaten sebelum dan setelah pemekaran di Provinsi Sumatera Selatan dikarenakan Pendapatan Asli Daerah (PAD) tidak mengalami perubahan; 4) diukur dari rasio ketergantungan keuangan daerah tidak terdapat perbedaan kinerja keuangan pemerintah daerah kabupaten sebelum dan setelah pemekaran di Provinsi Sumatera Selatan dikarenakan pendapatan transfer dengan total pendapatan daerah tidak mengalami perubahan.

\section{Saran}

1. Penelitian selanjutnya diharapkan agar dapat memperluas objek dan sampel penelitian dengan menambah kabupaten/kota lainnya yang mengalami pemekaran di Indonesia.

2. Penelitian selanjutnya diharapkan agar dapat melakukan penelitian dengan objek dan periode yang berbeda agar dapat diperoleh hasil yang lebih luas tentang dampak pemekaran terhadap kinerja keuangan pemerintah daerah.

DAFTAR PUSTAKA

Anggraeni, A. (2015). Pengaruh Belanja Modal Terhadap Kinerja Keuangan dengan PAD Sebagai Variabel Intervening. Jurnal Akuntansi. 1-18.

BAPPENAS, \& UNDP. (2008). Study Evaluasi Dampak Pemekaran Daerah 2001-2007. Jakarta : Building and Reinventing Desentralised Governance.

Imelda, E. (2015). Analisis Kinerja Keuangan Daerah Sebelum dan Sesudah Otonomi Daerah Studi kasus : Pemerintah Provinsi Kalimantan Barat. Jurnal Manajemen dan Bisnis. 1(3).

Kaho, \& Josef, R. (1997). Prospek Otonomi Daerah di Negara Republik Indonesia. Fak SospolUGM. Yogyakarta.

Meilinda, K. (2010). Analisa Kemampuan Keuangan Daerah dalam Menjalankan Otonomi Daerah di Kabupaten Ogan Komering Ilir. Tesis. Program Pasca Sarjana. Universitas Sriwijaya.

Mengkuningtyas, Y. (2015). Analisis Perbandingan Kinerja Keuangan Pemerintah Daerah Kota/Kabupaten di Indonesia Sebelum dan Setelah Pemekaran. Jurnal Akuntansi, 1-21.

Mianti, R. (2014). Analisis Kinerja Keuangan Pemerintah Daerah seProvinsi Bengkulu Sepuluh Tahun Terakhir. Skripsi. FEB. Universitas Bengkulu.

Sucandrawati, \& Ni, K.,A. (2016). Analisis Perbandingan Kinerja Keuangan Pemerintah Daerah Provinsi Lampung Sebelum dan Setelah Pemekaran Wilayah. 
Tesis. Bandar Lampung: Program Magister Akuntansi Universitas Lampung.

Susantih, H., \& Yulia, S. (2009). Perbandingan Indikator Kinerja Keuangan Pemerintah Propinsi se-Sumatera Bagian Selatan.
Tesis. Program Pasca Sarjana Universitas Sriwijaya. Palembang. Wulansari, R. (2018). Analisis Kinerja Keuangan Pemerintah Daerah Kabupten Asahan Sebelum dan Sesudah Otonomi Daerah. Jurnal Akuntansi. 